\title{
Significance of planktonic ciliated protozoa in the Lower St. Lawrence Estuary: comparison with bacterial, phytoplankton, and particulate organic carbon
}

\author{
Télesphore Sime-Ngando ${ }^{1, *}$, Michel Gosselin ${ }^{2}$, Suzanne Roy ${ }^{3}$, Jean-Pierre Chanut ${ }^{2}$
}

${ }^{1}$ CNRS URA-1944, Biologie Comparée des Protistes, Université Blaise Pascal (Clermont-Ferrand II), les Cézeaux, F-63177 Aubière Cedex, France

${ }^{2}$ Département d'Océanographie, Université du Québec à Rimouski, 310 allée des Ursulines, Rimouski, Québec, Canada G5L. 3A1

${ }^{3}$ INRS-Océanologie, 310 allée des Ursulines, Rimouski, Québec, Canada G5L 3A1

\begin{abstract}
To investigate the potential role of microzooplankton as trophic links in the Lower St. Lawrence Estuary (LSLE, ca $48^{\circ} 50^{\prime} \mathrm{N}, 68^{\circ} 10^{\circ} \mathrm{W}$ ), the importance of ciliate carbon biomass (CilC) was evaluated in relation to bacterial (BactC), phytoplankton (PhytoC), and particulate organic (POC) carbon, from May to September 1992. These variables generally peaked in the upper $10 \mathrm{~m}$ of the water column. Their seasonal peaks occurred in June and July when water temperature and stratification index were at their highest levels. CilC averaged 22, 8, and $4 \%$ of BactC, PhytoC, and POC, respectively. Compared to bacteria, ciliates appeared able to respond more rapidly to an increase in phytoplankton biomass, and were under higher predation pressure. Ciliates were dominated by individuals with sizes (19 to $187 \mu \mathrm{m}$ ) up to 15 times larger than that of the blooming diatoms. Direct observations revealed protozoan individuals with up to 10 ingested bloom-forming algal cells within their body. Microzooplankton grazing rates (estimated in July 1992 using a dilution technique) in unscreened water samples from the depth of maximum chlorophyll a concentration represented up to $70 \%$ (mean $\pm \mathrm{SD}=54 \pm 21 \%$ ) of the phytoplankton growth rates. Microzooplankton grazing rates in prescreened $(<160 \mu \mathrm{m})$ water samples were up to $60 \%$ higher than in unscreened samples. We conclude that this was due to the removal of a substantial fraction of herbivorous micrograzers by metazoan zooplankton present in unscreened samples, though the phytoplankton assemblage was in a blooming state. These results thus suggest that herbivory by microzooplankton can enhance trophic transfer from the microbial food web to higher trophic levels in the LSLE. This may explain the apparent paradox of low annual algal production and large standing stock of metazoan zooplankton in this environment.
\end{abstract}

KEY WORDS: Ciliates - Microzooplankton grazing - Bacteria - Phytoplankton P Particulate organic carbon - Estuaries

\section{INTRODUCTION}

Even though the role of ciliated protozoan assemblages as primary or indirect food sources for fish has been known for some time (Ryder 1881), their potential importance as key intermediates in aquatic food webs has only come to light relatively recently (Porter et al. 1979, Sherr \& Sherr 1984). Attention has focused more

\footnotetext{
-E-mail: simengando@cicc.univ-bpclermont.fr
}

recently on their roles as (1) grazers of bacteria (Rivier et al. 1985, Sherr \& Sherr 1987), autotrophic picoplankton (Bernard \& Rassoulzadegan 1993) or microalgae (Verity 1991); (2) agents of nitrogen (Paasche \& Kristiansen 1982, Ferrier-Pagès \& Rassoulzadegan 1994) and phosphorus (Allali et al. 1994) regeneration; (3) mixotrophic primary producers (reviewed by Dolan 1992); (4) food sources for metazoan zooplankton (Stoecker \& Egloff 1987. Wiadnyana \& Rassoulzadegan 1989, Jonsson \& Tiselius 1990, Dolan 1991a, Hartmann et al. 1993) and fish larvae (De Mendiola 1974); (5) con- 
tributors to scattering of light, which has significant implications for remote sensing (Morel \& Ahn 1991); and (6) regulators of the rate of bacterial remineralization of sinking particles (Silver et al. 1984). A few attempts have been made to analyze and compare relationships of planktonic ciliates to other components of the trophic structure in both freshwater (Amblard et al. 1993, 1994) and marine (Rassoulzadegan et al. 1988, Dolan \& Coats 1990, Sieracki et al. 1993, Verity et al. 1993c, Stoecker et al. 1994) ecosystems.

The maritime portion of the St. Lawrence Estuary, often called the Lower St. Lawrence Estuary (LSLE), is characterized by high salinities ( $>25 \mathrm{psu}$ ) and pronounced stratification during summer (El-Sabh 1988, El-Sabh \& Silverberg 1990). Standing stocks of bacteria (Painchaud \& Therriault 1989) and large-sized metazoan zooplankton (Runge \& Simard 1990) in this region are as high as in other coastal waters in the northwest Atlantic. Metazoan zooplankton in the LSLE are typically dominated by large copepods and euphausiids, while small species are unusually low in number (cf. Fig. 3 in Runge \& Simard 1990). Fish larvae are also diverse and abundant in the LSLE (De Lafontaine 1990), suggesting an efficient trophic transfer from the lower to the higher trophic levels (Ryther 1969, Cushing 1971).

High flushing rates and strong stratification during the spring freshet are thought to delay the phytoplankton bloom until early summer in the year-round nutrient-rich LSLE (Therriault \& Levasseur 1985). Because of the relatively short phytoplankton bloom period (i.e. June and July), the annual primary production range in the LSLE ( 31 to $134 \mathrm{~g} \mathrm{C} \mathrm{m}^{-2} \mathrm{yr}^{-1}$ ) is at the low end of those of similar estuaries ( 60 to $500 \mathrm{~g} \mathrm{C} \mathrm{m}^{-2} \mathrm{yr}^{-1}$ ) in temperate regions in the northern hemisphere (see comparative Table in Therriault \& Levasseur 1985). Furthermore, the phytoplankton bloom in the LSLE is made up of small diatoms $(<25 \mu \mathrm{m})$ belonging to the genera Skeletonema, Thalassiosira and Chaetoceros (Levasseur et al. 1984), which are likely to be an inadequate prey source for dominant large metazoans. Comprehensive reviews on the ecology of phytoplankton (Levasseur et al. 1984, Therriault \& Levasseur 1985, Therriault et al. 1990) and zooplankton (Runge \& Simard 1990) in the LSLE are available.

The above comparisons between metazoan zooplankton and phytoplankton imply that microzooplankton may be important in the trophic transfer from phytoplankton to fish in the LSLE. We hypothesize that in this environment, ciliated protozoa play a major role as trophic links between phytoplankton and metazoan zooplankton. This hypothesis is partly supported by the facts that ciliates (1) are sometimes dominated by large individuals $(>50 \mu \mathrm{m})$ in marine waters (Sime-
Ngando et al. 1992); (2) are rarely or never limited by food availability in neritic waters (Nielsen \& Kiørboe 1994); and (3) may be preferred over algae as a food source by metazoans in estuarine (Robertson 1983, Gifford \& Dagg 1988), marine (Wiadnyana \& Rassoulzadegan 1989, Stoecker \& Capuzzo 1990) and freshwater (Hartmann et al. 1993) environments. Recently, Ohman \& Runge (1994) suggested that heterotrophic microplankton - including ciliates and dinoflagellates presumed to be heterotrophic - may be the main prey resource for net lipid synthesis and egg production for the dominant copepod (i.e. Calanus finmarchicus) in the low-chlorophyll waters of the nearby Gulf of St. Lawrence, in late June and early July.

As a first step in evaluating the above hypothesis on the major role of microzooplankton as trophic link in the LSLE, we undertook a multidisciplinary investigation of physical and biological processes in the upper water column of this area. We were particularly interested in the trophodynamics of microplanktonic organisms and particulate organic matter. Here we report on the spatial distribution of planktonic ciliate biomass from May to September 1992, and their relationships with bacterial, phytoplankton, and particulate organic carbon. In addition, we measured the grazing rates of microzooplankton in the plankton community of July 1992, using the dilution technique of Landry \& Hassett (1982).

\section{METHODS}

Located in a temperate-subarctic climate between $47^{\circ}$ and $49^{\circ} \mathrm{N}$, the St. Lawrence Estuary links the St. Lawrence River to the Gulf of St. Lawrence, which separates the estuary from the North Atlantic proper by a distance of about $1000 \mathrm{~km}$ (Fig. 1). The $350 \mathrm{~km}$ long estuary is divided into 2 natural parts by a $50 \mathrm{~m}$ deep sill, which isolates the $350 \mathrm{~m}$ deep and stratified Lower Estuary from the shallow $(<100 \mathrm{~m})$ and partially mixed Upper Estuary (Runge \& Simard 1990). Sampling was conducted at 6 stations (except in May, when only 4 stations were visited) along 2 transects crossing the LSLE during the last weeks of May, June, July and September 1992 (Fig. 1, Table 1). These stations are located in the region of the freshwater plume of 2 major rivers on the north shore of the LSLE, the Manicouagan and Aux-Outardes Rivers, which are responsible for the stabilization of the surface water column all year round. This region, often called the plume region, is the most productive area of the whole St. Lawrence Estuary because of the mixing of surface waters with nutrient-rich waters upwelled and advected from upstream regions (Therriault \& Levasseur 1985). 
Fig. 1. Map of the Lower St. Lawrence Estuary showing the sampling stations (cf. Table 1 for coordinates) organized along 2 transects crossing the lower estuary

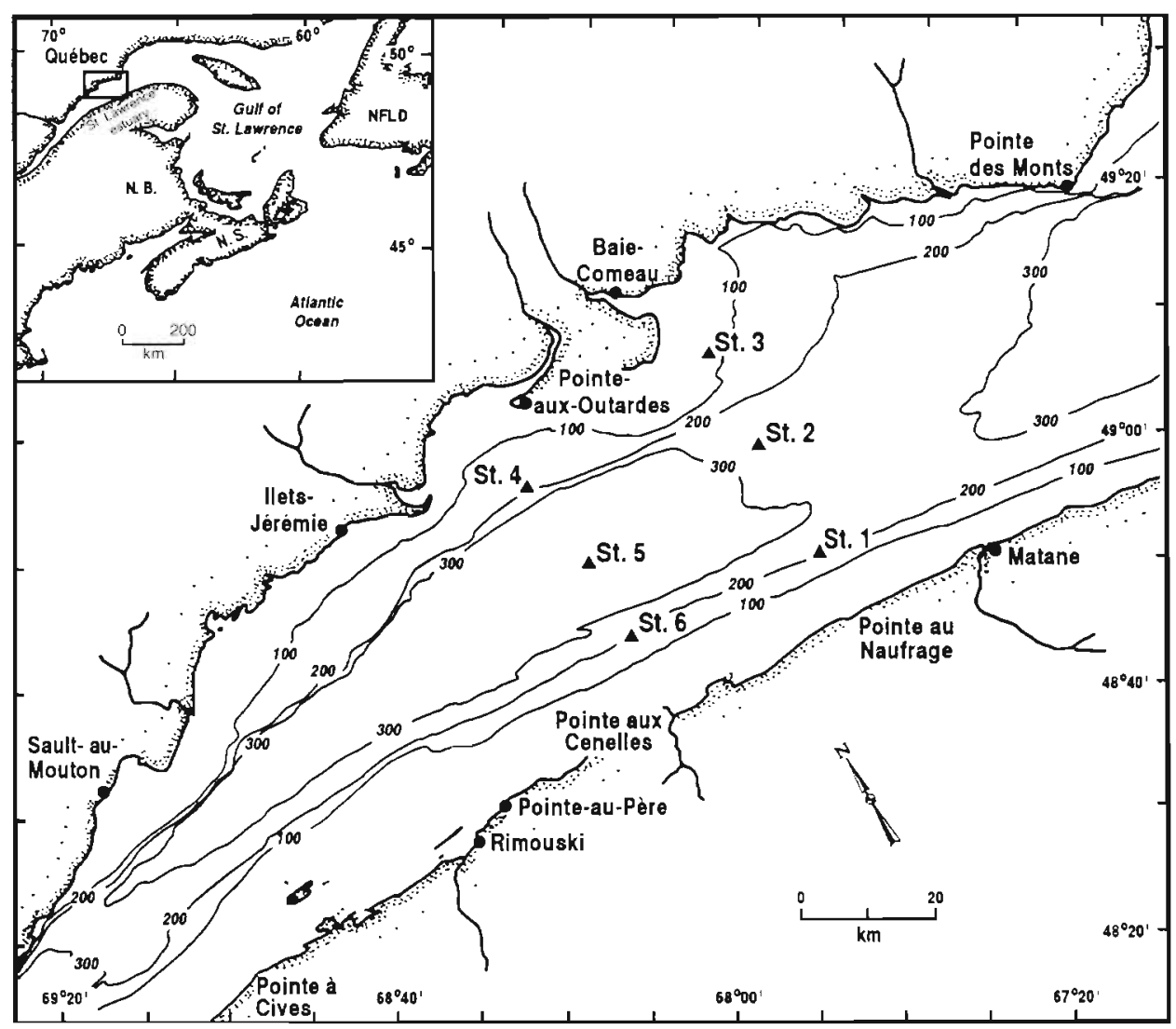

Using a rosette sampler equipped with a Guildline digital CTD, a Seatech transmissometer and 51 Niskin bottles, vertical profiles of water temperature, salinity and turbidity were determined from 0 to $150 \mathrm{~m}$ (except at $\mathrm{Stn} 3$, from 0 to $60 \mathrm{~m}$ ) and water was collected at 4 or 5 depths (usually at 1,5 and/or 10,25 and $70 \mathrm{~m}$ ). The vertical profile of irradiance in the water column was determined with a $2 \pi$ submarine photometer (Kahl Scientific Instrument, model 268WA300). Subsamples were first drawn from each Niskin bottle for the determination of dissolved ammonium and bacterial abundance. Niskin bottles were then emptied into individual dark plastic carboys, which were kept at the ambient cold temperature of the wet laboratory.

Ammonium was determined on filtered seawater (Whatman GF/F filter) by the alternative method described in Parsons et al. (1984). Various measurements of seston, phytoplankton, bacteria and ciliated protozoa were then performed on the water samples.

Two $250 \mathrm{ml}$ subsamples were filtered onto combusted Whatman GF/F filters which were stored frozen in a desiccator for later determination of particulate organic carbon (POC) using a Perkin Elmer ${ }^{(3)}$ elemental analyzer (Sharp 1974). Chlorophyll a (chl a) was determined fluorometrically (Yentsch \& Menzel 1963, HolmHansen et al. 1965) following retention of particles from $250 \mathrm{ml}$ samples on $0.4 \mu \mathrm{m}$ polycarbonate Poretic filters, and extraction in $90 \%$ acetone in the dark and under refrigeration for $24 \mathrm{~h}$. Phytoplankton carbon biomass (PhytoC) was derived from chl a and POC measurements as suggested by Sakshaug et al. (1983). The relative contribution of heterotrophic organisms and detritus to POC was estimated from least-squares linear regression analysis of the relationship between POC and chl a. The $y$-intercept was taken as a measure of the POC attributable to heterotrophs and detri-

Table 1. Coordinates of sampling sites (cf. Fig. 1) in the central part of the Lower St. Lawrence Estuary. Samples were taken during the last weeks of May, June, July and September 1992

\begin{tabular}{|cc|}
\hline Stn & Location \\
\hline 1 & $48^{\circ} 51^{\prime} \mathrm{N}, 67^{\circ} 52^{\prime} \mathrm{W}$ \\
2 & $48^{\circ} 59^{\prime} \mathrm{N}, 67^{\circ} 59^{\prime} \mathrm{W}$ \\
$3^{\mathrm{a}}$ & $49^{\circ} 07^{\prime} \mathrm{N}, 68^{\circ} 05^{\prime} \mathrm{W}$ \\
$4^{\mathrm{a}}$ & $48^{\circ} 57^{\prime} \mathrm{N}, 68^{\circ} 26^{\prime} \mathrm{W}$ \\
5 & $48^{\circ} 50^{\prime} \mathrm{N}, 68^{\circ} 19^{\prime} \mathrm{W}$ \\
6 & $48^{\circ} 44^{\prime} \mathrm{N}, 68^{\circ} 14^{\prime} \mathrm{W}$ \\
& \\
\hline
\end{tabular}


tus and was subtracted from total POC in order to calculate the phytoplankton C:chl a ratios (Sakshaug et al. 1983). To account for differences in carbon composition due to differences in species assemblages, an independent regression analysis was conducted for each cruise (Table 2).

Subsamples were preserved with acidic Lugol's solution (Throndsen 1978) for phytoplankton identification and enumeration (Lund et al. 1958). The abundance of small phytoplankton $(<3 \mu \mathrm{m})$ was not determined.

To preserve bacteria, $20 \mathrm{ml}$ samples were fixed with buffered, alkaline formaldehyde (final concentration $3 \% \mathrm{v} / \mathrm{v}$, from commercial formaldehyde $40 \%$ ). Subsamples (2 to $5 \mathrm{ml}$ ) were treated with 4',6-diamidino-2phenylindole (DAPI) (Porter \& Feig 1980) and filtered onto $0.2 \mu \mathrm{m}$ pore-size black polycarbonate filters, using $1.2 \mu \mathrm{m}$ pore-size cellulose acetate backing filters to obtain a uniform distribution of cells. Filters were mounted between a slide and glass cover slip with a nonfluorescent immersion oil prior to examination by epifluorescence microscopy. At least 500 bacterial cells were counted and sized with a micrometer in 20 to 50 fields as previously described (cf. Sime-Ngando et al. 1991). A blank was routinely examined to control for contamination of equipment and reagents. Bacterial carbon biomass (BactC) was calculated with the established equation $Y=88.6 X^{0.59}$, where $X$ denotes mean cell volume $\left(\mu \mathrm{m}^{3}\right)$ per sample and $Y$ denotes cell protein ( $\mathrm{f} g$ ), with the $\mathrm{C}$ :protein ratio being 0.86 (Simon \& Azam 1989). It is important to note here that there is a possibility of overestimation of numbers and biomass of bacteria by direct counts of cells stained with DAPI, which is a double-stranded DNA stain. The same observation can be made with the fluorochrome acridine orange, which binds to both DNA and RNA and appears to also stain other structures in the cell (e.g.

Table 2. Least-squares regression statistics between chlorophyll a (chl a) and particulate organic carbon (POC) concentration $(\mathrm{POC}=$ Slope $\times \mathrm{chl}$ a + POC-int $)$ in the Lower St. Lawrence Estuary during its late spring/early autumn development, 1992. Following the method of Sakshaug et al. [1983), POC-int. was taken as a measure of the POC attributable to heterotrophic organisms and detritus and was subtracted from total POC in the calculation of $C$ :chl a ratios for each sampling month. n: number of data points; SE: standard error on slope

\begin{tabular}{|lrrrrrrrr|}
\hline $\begin{array}{l}\text { Sampling } \\
\text { date }\end{array}$ & $\mathrm{n}$ & Slope & SE & POC-int. & $r^{2}$ & $p$ & C:chl a \\
\hline May & 16 & 87.3 & 12.7 & 119.5 & 0.77 & 0.0001 & 87.2 \\
Jun & 25 & 74.2 & 6.3 & 66.7 & 0.86 & 0.0001 & 74.3 \\
Juil & 25 & 51.4 & 10.1 & 187.2 & 0.53 & 0.0001 & 51.3 \\
Sep & 26 & 45.6 & 38.3 & 112.5 & 0.06 & 0.2455 & 46.2 \\
Overall & 92 & 66.8 & 4.32 & 116.9 & 0.73 & 0.0001 & 66.9 \\
\hline
\end{tabular}

the cell wall), resulting in a better estimation of bacterioplankton numbers and average cell volume than the DAPI staining method (Suzuki et al. 1993). Indeed, a recent study by Zweifel \& Hagström (1995) indicated that a substantial fraction (up to $98 \%$ ) of marine bacterial total counts derived from unspecific fluorescent staining techniques may be comprised of nonnucleoid-containing 'bacterial cells', which are really detrital 'ghosts'

To preserve ciliates, $250 \mathrm{ml}$ samples were fixed with basic Lugol solution (final concentration $0.5 \% \mathrm{v} / \mathrm{v}$ ) and ciliates were counted by Utermöhl's inverted microscope method (Sime-Ngando et al. 1990), following sedimentation of 100 to $200 \mathrm{ml}$ subsamples for $24 \mathrm{~h}$. All samples were counted within 4 mo, because of significant loss occurring during longer storage (SimeNgando \& Grolière 1991). At least 200 cells of each representative taxon were counted in 1 or, if necessary, several subsamples (except in a few of the deepest samples) and identified to genus by consulting several taxonomic references (Marshall 1969, Corliss 1979, Small \& Lynn 1985). Ciliate biomasses were calculated from the mean cell volume of each taxon, which was determined from measurements on enlarged phasecontrast micrographs. The carbon biomass (CilC) was then estimated according to Putt \& Stoecker (1989), assuming that $1 \mu \mathrm{m}^{3}=0.19 \mathrm{pg} \mathrm{C}$.

Microzooplankton grazing rates were measured by conducting seawater dilution experiments at the depth of chl a maximum for all survey stations in July 1992 The method and assumptions of the seawater dilution technique have been described by Landry \& Hassett (1982). Each experiment consisted of a series of 4 dilution treatments, each in duplicate (for a total of 8 different bottles), consisting of natural and filtered (0.2 $\mathrm{m}$ pore-size polycarbonate filters) seawater mixed in acid-cleaned, demineralized, water-rinsed, 2 l polycarbonate bottles in the ratios 1:0 (100\% natural seawater): $3: 1(75 \%), 1: 1(50 \%)$, and $1: 3(25 \%)$. Bottles were adjusted to light intensities corresponding to sampled depths with layers of neutral density screen and incubated for $24 \mathrm{~h}$ in Plexiglas incubators cooled with flowing surface seawater. Nutrient depletion during incubations was considered unlikely due to the general high ambient nutrient levels throughout the year in the LSLE (Therriault \& Levasseur 1985, Therriault et al. 1990); therefore neither $\mathrm{N}$ nor $\mathrm{P}$ was added. At Stns 1 and 5, 2 sets of dilution experiments with unscreened and $<160 \mu \mathrm{m}$ prescreened (i.e. with only microzooplankton present) seawater were conducted. An additional experiment was done with $70 \mathrm{~m}$ deep seawater at Str 6 to examine vertical variations in microzooplankton grazing rates.

The apparent growth rates of phytoplankton were calculated from the equation $S_{i}=S_{0} \mathrm{e}^{(k-g) t}$, where $S$ 
denotes the phytoplankton standing stock measured from chl a at the beginning $\left(S_{0}\right)$ and the end $\left(S_{t}\right)$ of the incubations, $k$ the instantaneous coefficient of phytoplankton growth, $g$ the instantaneous coefficient of phytoplankton mortality considered as microzooplankton grazing rate, and $t$ the time interval between the beginning and the end of the incubations (i.e. $24 \mathrm{~h}$ ) (Landry \& Hassett 1982). Coefficients $k$ and $g$ were determined from least-squares linear regression analysis of the relationship between the rate of change of $c h l a$ and the fraction of natural seawater. Clearance rate estimates were calculated by dividing microzooplankton grazing coefficient estimates by initial densities of microzooplankton, i.e. ciliates (from inverted microscopical counts) and heterotrophic microflagellates (>20 $\mu \mathrm{m}$, including dinoflagellates; from epifluorescence microscopical counts). Heterotrophic nanoflagellates $(<20 \mu \mathrm{m})$ were not taken into account in the calculation of clearance rate estimates because they are generally hypothesized to feed on bacteria.

BactC, CilC, PhytoC and POC were tested using analysis of variance (ANOVA) for differences between sampling months, stations, and depths. The null hypothesis was that no differences existed among mean values of the biological variables between sampling months, stations or depths, nor interactions among these 3 factors. Main effects and first-order interactions were tested using a 3-factor ANOVA associated with a factorial plan without replication (Sokal \& Rohlf 1981). All 3 factors are assumed to have fixed effects on biomasses. Because only 1 measurement was made for each combination of the 3 factors (i.e. absence of replicates), main effects and first-order interactions can be tested, whereas the second-order interaction does not exist, its effect being always nil. Biomass data were log-transformed to meet the assumptions of the analysis of variance.

Other statistical treatments consisted of linear correlation (Pearson correlation coefficient) and leastsquares regression analyses to establish the relationships between variables. When necessary, data were log-transformed to meet the normality assumption of least-squares regression analysis (Ricker 1973). To compensate for inherent bias in log-transformed equations, correction factors were calculated (CF = antilog $1.1513 \times$ RMS, where RMS is the residual mean square of the regression) (Neyman \& Scott 1960). To account for the possibility of underestimating the regression coefficient (or slope) when there was error in the independent variable, a model II or geometric mean slope was calculated as recommended by Ricker (1973), when seeking functional relationships.

Path analysis (Sokal \& Rohlf 1981) was used to explore causal relations between a physical variable (water temperature) and the biomasses of bacteria, cil- iates, and microalgae. Path analysis is an extension of multiple linear regression where hypotheses as to causal relations among variables can be assessed (Sokal \& Rohlf 1981, Legendre \& Legendre 1984). To do so, linear equations were written in order to specify the causal order among variables. In Fig. 6, for example, these equations are:

PhytoC $=p_{1 \mathrm{a}}$ temperature;

BactC $=p_{2 a}$ temperature $+p_{2 b}$ Phyto $\mathrm{C}$

$\mathrm{CilC}=p_{3 \mathrm{a}}$ temperature $+p_{3 \mathrm{~b}}$ BactC $+p_{3 c}$ Phyto $\mathrm{C}$.

Path coefficients $p$ are then estimated by multiple regressions on standardized variables. Path analysis was executed with the $\mathrm{R}$ package for multivariate data analyses of Legendre \& Vaudor (1991). The coefficients $p$ are interpreted in terms of their signs and relative magnitudes, rather than their individual statistical significance (Sokal \& Rohlf 1981).

\section{RESULTS}

\section{Hydrography}

The mean hydrographic conditions illustrated the typical seasonal forcing of the LSLE in summer (El Sabh 1988, El Sabh \& Silverberg 1990), with relatively small changes in the physical environment between sampling stations (Fig. 2). Warming ( 1.2-fold increase in water temperature) and significant stratification of the water column (defined as the difference between $\sigma_{\tau} 30 \mathrm{~m}$ and $\sigma_{\tau} 1 \mathrm{~m}$ ) were observed in June and July, associated with relatively low salinity $(\sim 28.4$ psu in June and July), which increased (to 29.2 psu) with September cooling. The mixed layer depth (defined as the depth where $\Delta \sigma_{\mathrm{\tau}} \mathrm{m}^{-1} \geq 0.2$ as in Therriault \& Levasseur 1985) and the euphotic layer depth (1\% surface light intensity) progressively increased during the sampling period. The mean depth of the euphotic layer in June and July was greater than the mean depth of the mixed layer (Fig. 2), a situation which is generally favorable to phytoplankton growth.

\section{Species composition}

Ciliated protozoan populations in the LSLE were dominated by members of the subclass Choreotrichia (orders Choreotrichida and Oligotrichida). This agrees with results from most open ocean (e.g. Sime-Ngando et al. 1992) and coastal (Smetacek 1981, Dolan 1991a, b) waters. Particularly dominant were the naked choreotrichs Laboea spp. (including L. crassula, L. conica, L. emergens and L. strobila), Lohmaniella oviformis, Strobilidium (formerly Lohmaniella) spiralis 

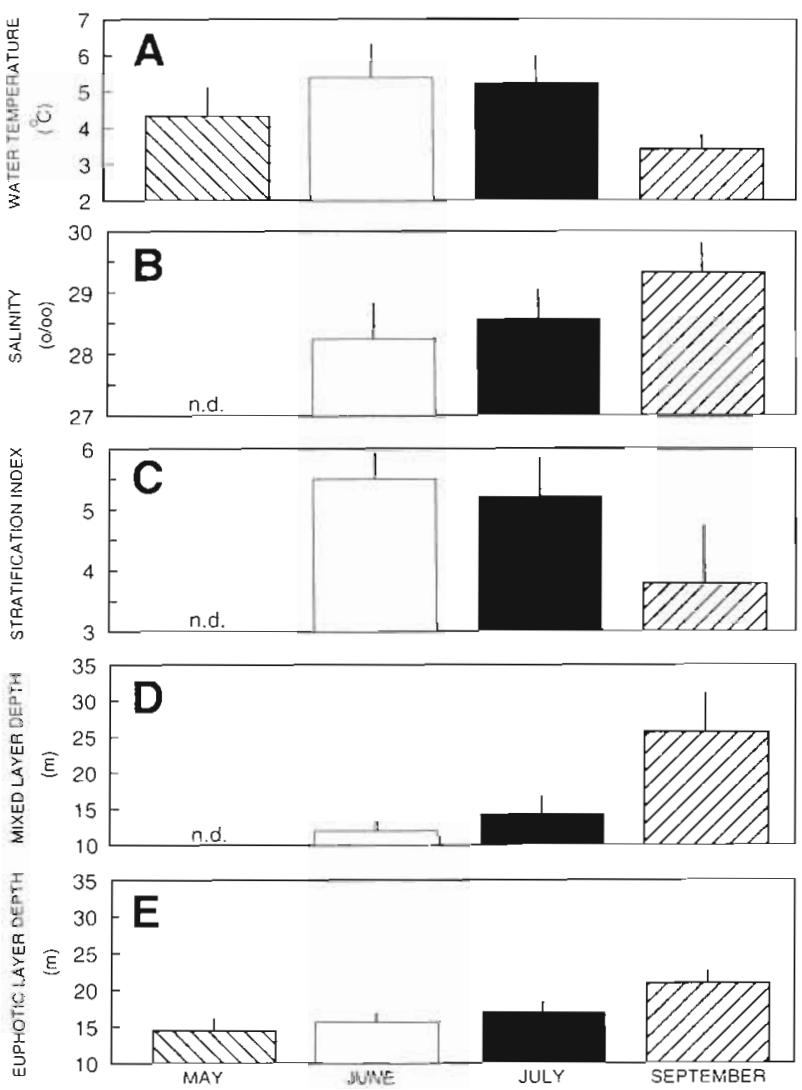

Fig. 2. Temporal variations for the lower estuary of (A) mean water temperature and $(B)$ mean salinity calculated from 0 to $50-70 \mathrm{~m},(\mathrm{C})$ mean of the stratification index $\left(\sigma_{\tau} 30 \mathrm{~m}\right.$ to $\sigma_{\tau}$ $1 \mathrm{~m}),(\mathrm{D})$ mean depth of the mixed layer, and (E) mean depth of the euphotic layer, from May to September 1992. The depth of the mixed layer is defined as the depth where $\Delta \sigma_{\tau} \mathrm{m}^{-1} \geq 0.2$ as in Therriault \& Levasseur (1985). Lines on bars represent the standard error of the mean, i.e. the variability between stations; n.d.: no data

Strombidinopsis spp., Strobilidium epacrum, and an unidentified choreotrich. Loricated choreotrichs were dominated by Tintinnopsis sp., Ptychocylis sp. and Helicostomella sp. Other common species were represented by haptorids (Mesodinium spp., Askenasia sp.), prostomatids (Balanion spp. and Urotricha spp.), an unidentified hypotrich, and an unidentified hypostome. Ciliates ranged in size from a $19 \mu \mathrm{m}$ Urotricha sp. to a large choreotrichous ciliate of $187 \mu \mathrm{m}$ length (dominant cells were 25 to $75 \mu \mathrm{m}$ in length), and were up to $>15$-fold larger than the dominant algae. Algal assemblages were dominated by microflagellates $(<10 \mu \mathrm{m})$ in May and September, by pennate diatoms $(<65 \mu \mathrm{m}$ in length) in June, and by centric diatoms $(<25 \mu \mathrm{m})$ in July. The dominant diatoms belonged to the genera Chaetoceros, Nitzschia, Skeletonema, and Thalassiosira. Phase contrast micrographs of the dominant ciliate and algal taxa are presented in Fig. 3.

\section{Standing stock}

Ciliate abundance (CilA) at the survey stations

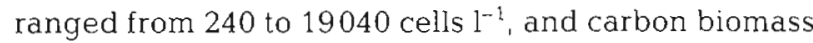
(CilC) from 0.2 to $51.6 \mu \mathrm{g} \mathrm{Cl}^{-1}$ (Table 3). Integrated to $70 \mathrm{~m}$ depth, CilA peaked in June at Stn 5 along with the mean water-column temperature, while CilC peaked at Stn 6 in May, coincidentally with the maximum values in chl a concentration and the derived PhytoC and POC (Table 4). Variables under study were significantly and positively intercorrelated, except for relationships between (1) chl a, PhytoC, and POC with water temperature; (2) CilA and bacterial abundance (BactA) with $\mathrm{POC}_{i}$ (3) CilA with chl $a_{i}$ and (4) CilA and CilC with bacterial carbon biomass (BactC), which were not statistically significant (Table 5). On average, integrated variables peaked in June (for BactA, CilA, and CilC) or July (for BactC, chl a, PhytoC, and POC) (Table 4)

\section{Temporal and spatial variability}

Analysis of variance indicated that sampled stations were not significantly different each from other (for all biomass variables), while significant differences were indicated among sampling months as well as among sampled depths (for BactC, CilC, PhytoC and POC). In addition, there was a significant month-by-depth interaction (for BactC, PhytoC and POC) while no signifi-

Table 3. Acronym, and minimum, mean \pm standard deviation and maximum values for the main variables under study

\begin{tabular}{|c|c|c|c|c|}
\hline Variable & Acronym & Min. & Mean $\pm S D$ & Max. \\
\hline \multicolumn{5}{|l|}{ Bacteria } \\
\hline $\begin{array}{l}\text { Abundance } \\
\left(10^{9} \text { cells } l^{-1}\right)\end{array}$ & BactA & 0.12 & $2.27 \pm 2.09$ & 6.71 \\
\hline 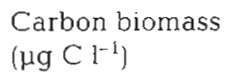 & BactC & 0.55 & $44.44 \pm 45.34$ & 146.70 \\
\hline \multicolumn{5}{|l|}{ Ciliates } \\
\hline $\begin{array}{l}\text { Abundance } \\
\left(10^{3} \text { cells } 1^{-1}\right)\end{array}$ & CilA & 0.24 & $4.43 \pm 4.34$ & 19.04 \\
\hline $\begin{array}{l}\text { Carbon biomass } \\
\left(\mu g \mathrm{Cl}^{-1}\right)\end{array}$ & $\mathrm{CilC}$ & 0.23 & $11.17 \pm 11.19$ & 51.59 \\
\hline \multicolumn{5}{|l|}{ Phytoplankton } \\
\hline $\begin{array}{l}\text { Chlorophyll a } \\
\left(\mu \mathrm{g} \mathrm{l}^{-1}\right)\end{array}$ & $\mathrm{Chla}$ & 0.03 & $2.05 \pm 2.39$ & 9.63 \\
\hline $\begin{array}{l}\text { Carbon biomass } \\
\left(\mu \mathrm{g} \mathrm{C}{ }^{-1}\right)\end{array}$ & PhytoC & 1.57 & $132.64 \pm 158.88$ & 721.75 \\
\hline \multicolumn{5}{|c|}{ Total organic particles } \\
\hline $\begin{array}{l}\text { Carbon biomass } \\
\left(\mu \mathrm{g} \mathrm{C}^{-1}\right)\end{array}$ & $\mathrm{POC}$ & 54.74 & $254.20 \pm 187.20$ & 833.34 \\
\hline
\end{tabular}


Table 4. Spatial and temporal variations of the main variables under study, in the Lower St. Lawrence Estuary during its late spring/early autumn development, 1992. Data integrated from the surface to $70 \mathrm{~m}$ depth. Acronyms as in Table 3 . T: mean water temperature from 0 to $70 \mathrm{~m}$

\begin{tabular}{|c|c|c|c|c|c|c|c|c|c|}
\hline $\begin{array}{l}\text { Sampling } \\
\text { date }\end{array}$ & $\operatorname{Stn}{ }^{d}$ & $\begin{array}{c}\text { BactA } \\
\left(10^{14} \text { cells } \mathrm{m}^{-2}\right)\end{array}$ & $\begin{array}{c}\mathrm{BactC} \\
\left(\mathrm{g} \mathrm{C}^{-2}\right)\end{array}$ & $\begin{array}{l}\text { CilA } \\
\left(10^{8} \text { cells } \mathrm{m}^{-2}\right)\end{array}$ & $\begin{array}{c}\mathrm{CilC} \\
\left(\mathrm{g} \mathrm{C} \mathrm{m}^{-2}\right)\end{array}$ & $\begin{array}{c}\mathrm{Chl} a \\
\left(\mathrm{~g} \mathrm{~m}^{-2}\right)\end{array}$ & $\begin{array}{c}\text { Phytoc } \\
\left(\mathrm{gC} \mathrm{m}^{-2}\right)\end{array}$ & $\begin{array}{c}P O C \\
\left(\mathrm{~g} \mathrm{~m}^{-2}\right)\end{array}$ & $\begin{array}{c}\mathrm{T} \\
\left({ }^{\circ} \mathrm{C}\right)\end{array}$ \\
\hline \multirow[t]{6}{*}{$\mathrm{May}^{\mathrm{b}}$} & 1 & 0.21 & 0.30 & 0.54 & 0.21 & 0.04 & 3.79 & 7.26 & 5.25 \\
\hline & 2 & 0.21 & 0.27 & 0.71 & 0.15 & 0.02 & 2.15 & 8.55 & 4.15 \\
\hline & 5 & 0.26 & 0.33 & 1.96 & 0.42 & 0.03 & 2.99 & 9.68 & 4.23 \\
\hline & 6 & 0.38 & 0.55 & 4.56 & 1.52 & 0.31 & 27.29 & 44.28 & 3.76 \\
\hline & Average & 0.26 & 0.36 & 1.94 & 0.57 & 0.10 & 9.06 & 17.44 & \\
\hline & $\mathrm{SD}$ & 0.08 & 0.13 & 1.86 & 0.64 & 0.14 & 12.18 & 17.92 & \\
\hline \multirow[t]{8}{*}{ June } & 1 & 1.92 & 3.11 & 1.84 & 0.51 & 0.08 & 6.27 & 11.77 & 5.85 \\
\hline & 2 & 1.91 & 1.54 & 1.21 & 0.28 & 0.07 & 4.87 & 6.50 & 4.03 \\
\hline & 3 & 2.16 & 3.37 & 6.10 & 0.88 & 0.19 & 13.93 & 17.51 & 5.23 \\
\hline & 4 & 3.12 & 5.38 & 5.08 & 1.02 & 0.15 & 10.96 & 15.74 & 4.81 \\
\hline & 5 & 2.78 & 3.97 & 7.91 & 1.31 & 0.14 & 10.74 & 16.45 & 7.13 \\
\hline & 6 & 1.88 & 3.47 & 1.61 & 0.50 & 0.08 & 6.22 & 9.06 & 5.36 \\
\hline & Average & 2.30 & 3.47 & 3.96 & 0.75 & 0.12 & 8.83 & 12.84 & \\
\hline & $\mathrm{SD}$ & 0.53 & 1.25 & 2.79 & 0.39 & 0.05 & 3.56 & 4.45 & \\
\hline \multirow[t]{8}{*}{ July } & 1 & 2.66 & 6.40 & 1.23 & 0.42 & 0.26 & 13.51 & 25.31 & 4.12 \\
\hline & 2 & 1.96 & 4.63 & 0.78 & 0.32 & 0.18 & 9.40 & 17.14 & 4.30 \\
\hline & 3 & 2.07 & 4.86 & 1.65 & 0.67 & 0.19 & 9.82 & 20.14 & 5.10 \\
\hline & 4 & 2.27 & 5.20 & 1.97 & 0.77 & 0.21 & 10.75 & 20.79 & 6.00 \\
\hline & 5 & 2.23 & 4.96 & 1.22 & 0.66 & 0.28 & 14.53 & 21.18 & 5.52 \\
\hline & 6 & 2.10 & 4.94 & 1.79 & 0.65 & 0.16 & 7.97 & 16.38 & 6.39 \\
\hline & Average & 2.21 & 5.17 & 1.44 & 0.58 & 0.21 & 11.00 & 20.16 & \\
\hline & $S D$ & 0.24 & 0.63 & 0.44 & 0.17 & 0.05 & 2.53 & 3.21 & \\
\hline \multirow[t]{8}{*}{ September } & 1 & 0.20 & 0.26 & 3.53 & 0.66 & 0.03 & 1.21 & 8.20 & 4.70 \\
\hline & 2 & 0.32 & 0.40 & 1.39 & 0.22 & 0.02 & 0.83 & 12.00 & 3.98 \\
\hline & 3 & 0.47 & 0.56 & 1.12 & 0.19 & 0.01 & 0.33 & 10.41 & 2.62 \\
\hline & 4 & 0.16 & 0.22 & 0.92 & 0.26 & 0.01 & 0.58 & 4.92 & 3.28 \\
\hline & 5 & 0.19 & 0.19 & 1.13 & 0.22 & 0.01 & 0.65 & 7.46 & 3.23 \\
\hline & 6 & 0.17 & 0.22 & 0.10 & 0.17 & 0.03 & 1.25 & 5.91 & 3.37 \\
\hline & Average & 0.25 & 0.31 & 1.37 & 0.29 & 0.02 & 0.81 & 8.15 & \\
\hline & $\mathrm{SD}$ & 0.12 & 0.14 & 1.15 & 0.19 & 0.01 & 0.36 & 2.68 & \\
\hline \multirow{2}{*}{\multicolumn{2}{|c|}{$\begin{array}{l}\text { Overall mean } \\
\text { SD }\end{array}$}} & 1.35 & 2.51 & 2.20 & 0.55 & 0.11 & 7.27 & 14.39 & \\
\hline & & 1.06 & 2.24 & 1.99 & 0.37 & 0.10 & 6.55 & 8.89 & \\
\hline
\end{tabular}

Table 5. Significant Pearson correlation coefficients ( $r$ ) between the integrated variables (cf. Table 4 ) under study. $\mathrm{df}=20, \mathrm{r}=0.42^{*}$ for $\mathrm{p} \leq 0.05$, $r=0.53 \cdots$ for $p \leq 0.01, r=0.65 \cdots$ for $p \leq 0.001$; ns: not significant. Acronyms as in Table 3

\begin{tabular}{|c|c|c|c|c|c|c|c|}
\hline & BactA & BactC & CilA & CilC & $\mathrm{Chl} a$ & PhytoC & POC \\
\hline Temp. & $0.64^{*}$ & $0.60^{\circ}$ & $0.47^{\circ}$ & $0.51^{\circ}$ & ns & ns & ns \\
\hline Bact $A$ & & $0.94^{\cdots}$ & $0.42^{\circ}$ & $0.47^{\circ}$ & $0.64^{*}$ & $0.50^{\circ}$ & ns \\
\hline BactC & & & ns & ns & $0.72 \cdots$ & $0.52^{\circ}$ & $0.42^{\circ}$ \\
\hline CilA & & & & $0.85^{\cdots} \cdot$ & ns & $0.50^{\circ}$ & ns \\
\hline CilC & & & & & $0.67 \cdots$ & $0.80^{\cdots} \cdot$ & $0.73^{\cdots}$ \\
\hline Chl a & & & & & & $0.93 \cdots$ & $0.88^{\cdots}$ \\
\hline PhytoC & & & & & & & $0.94^{\cdots}$ \\
\hline
\end{tabular}

cant station-induced interaction was indicated (for all biomass measurements) (Table 6). Accordingly, biological data sets (i.e. BactA, BactC, CilA, CilC, chl a, and POC) for each sampling month were pooled and treated as replicates in the vertical profiles presented in Fig. 4. During the study period, these biological variables generally peaked in the upper $10 \mathrm{~m}$ of the water column (and decreased with depth, except in September when differences between surface and deep waters were generally less pronounced) and exhibited highest seasonal concentrations in 


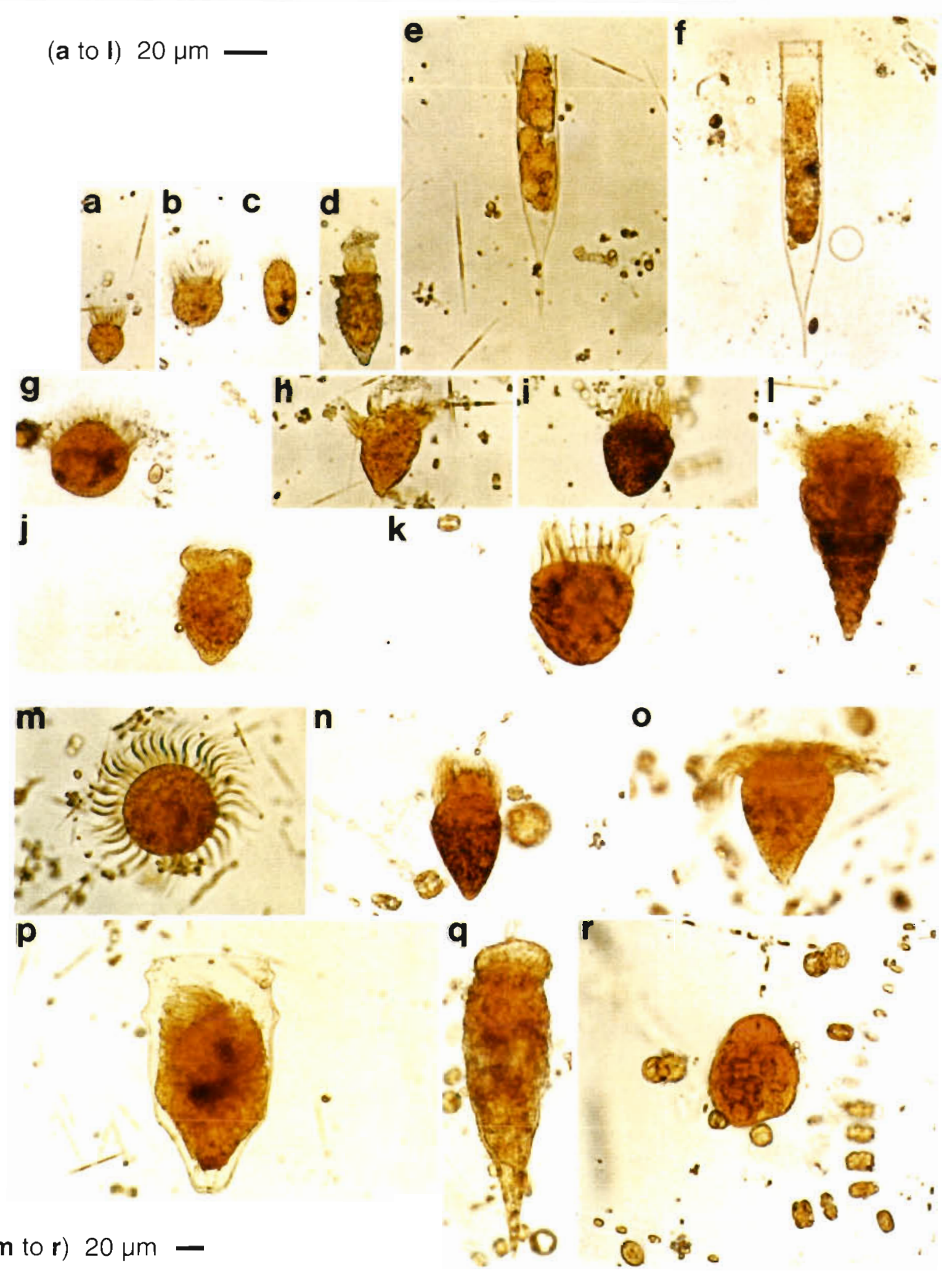

Fig. 3. Dominant ciliates in the Lower St. Lawrence Estuary during its late spring/early autumn development, 1992. Organisms identified as follows: (a) Lohmaniella oviformis; (b) Strombidinopsis sp.; (c) unknown hypotrich; (d) Tintinnopsis sp.; (e, f) Helicostomella sp., note cell division in (e); (g) Askenasia sp.; (h) Tontonia sp.; (i) Strombidium cf. acutum.; (j) unknown choreotrich; (k) Laboea cf. crassula.; (1) Laboea strobila; (m) Strobilidium spiralis; (n) Laboea cf. conica; (o) Strobilidium cf. epacrum; (p) Ptychocylis sp.i (q) unknown choreotrich; $(r)$ an unidentified phagotrophic protozoa (likely a heterotrophic naked dinoflagellate) sampled in July 1992 with at least 8 visible bloom-forming diatom cells (Thalassiosira sp.) within its body. Note the concentration of Thalassiosira sp. in the protozoan body, and the distortion of the protozoa likely due to grazing activity. Note the size difference between ciliates and the blooming diatoms: Nitzschia delicatissima (e), Thalassiosira nordenskioeldii (f), Chaetoceros sp. ( $\mathrm{g}$ ), Thalassiosira sp. and Skeletonema sp. (n) 
Table 6. Three-way factorial analysis of variance without replication concerning the effects of time of year (months), sampling stations and sampling depths on the standing stocks of variables under study. Data are log-transformed. The source of variation is subdivided into 3 main effects and 3 first-order interactions, Month $\times$ Depth, Month $\times$ Stn and Stn $\times$ Depth. - Significant at $1 \%$; ns: not significant. Acronyms as in Table 3

\begin{tabular}{|lcccc|}
\hline Source of variation & BactC & CilC & PhytoC & POC \\
\hline Month &.. &.. &.. &.. \\
Stn & ns & ns & ns & ns \\
Depth &.. &.. &.. &.. \\
Month $\times$ Depth &.. & ns &.. &. \\
Month $\times$ Stn & ns & ns & ns & ns \\
Stn $\times$ Depth & ns & ns & ns & ns \\
\hline
\end{tabular}

June and July. Highest CilA and CilC were observed in June at $1 \mathrm{~m}$, corresponding to highest Bact $\mathrm{A}$ and BactC (Fig. 4).

\section{Relationships with phytoplankton}

Linear least-squares regression analyses showed positive and significant relationships between PhytoC and BactC, as well as between PhytoC and CilC. Model I slopes were substantially less than 1 in both cases, while model II slopes were at about 1 for PhytoC versus $\mathrm{BactC}$, and at 0.81 for PhytoC versus CilC. In both models, the slope of the regression line linking PhytoC to BactC was greater than that linking PhytoC to CilC (Table 7 ).

The ratios of CilC:PhytoC and BactC:PhytoC increased with decreasing PhytoC (Fig. 5) to maximum values of 1.9 and 5.0, respectively. The maximum ratio of CilC:PhytoC corresponded to a PhytoC level of $4 \mu \mathrm{g}$ $\mathrm{Cl}^{-1}\left(=0.09 \mu \mathrm{g} \mathrm{Chl} \mathrm{a} \mathrm{l}^{-1}\right)$, which is 2 -fold higher than the

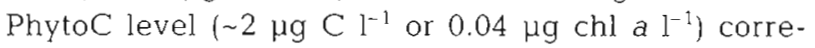
sponding to the maximum BactC:PhytoC ratio. As compared to the log-log relationship between CilC:PhytoC

Table 7 Linear regression statistics for the relationships between bacteria and ciliates versus phytoplankton. All values were log-transformed. Predictions converted to arithmetic scale must be multiplied by $C F$, the correction factor. The model II (geometric mean) slope is provided as an estimate of the functional slope when there is error in the independent variable. In all cases, $n=92$ and $p=0.0001$. Acronyms as in Table 3. SE: standard error

\begin{tabular}{|lrrrrr|}
\hline$Y, X$ & Slope \pm SE & $Y$-int. & $r^{2}$ & CF & $\begin{array}{c}\text { Model II } \\
\text { slope }\end{array}$ \\
\hline BactC, PhytoC & $0.68 \pm 0.08$ & 0.09 & 0.46 & 1.53 & 1.01 \\
CilC, PhytoC & $0.51 \pm 0.07$ & -0.07 & 0.40 & 1.25 & 0.81 \\
\hline
\end{tabular}
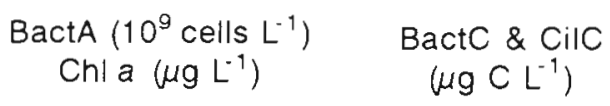

BactC \& CilC (ug $\left.C L^{-1}\right)$
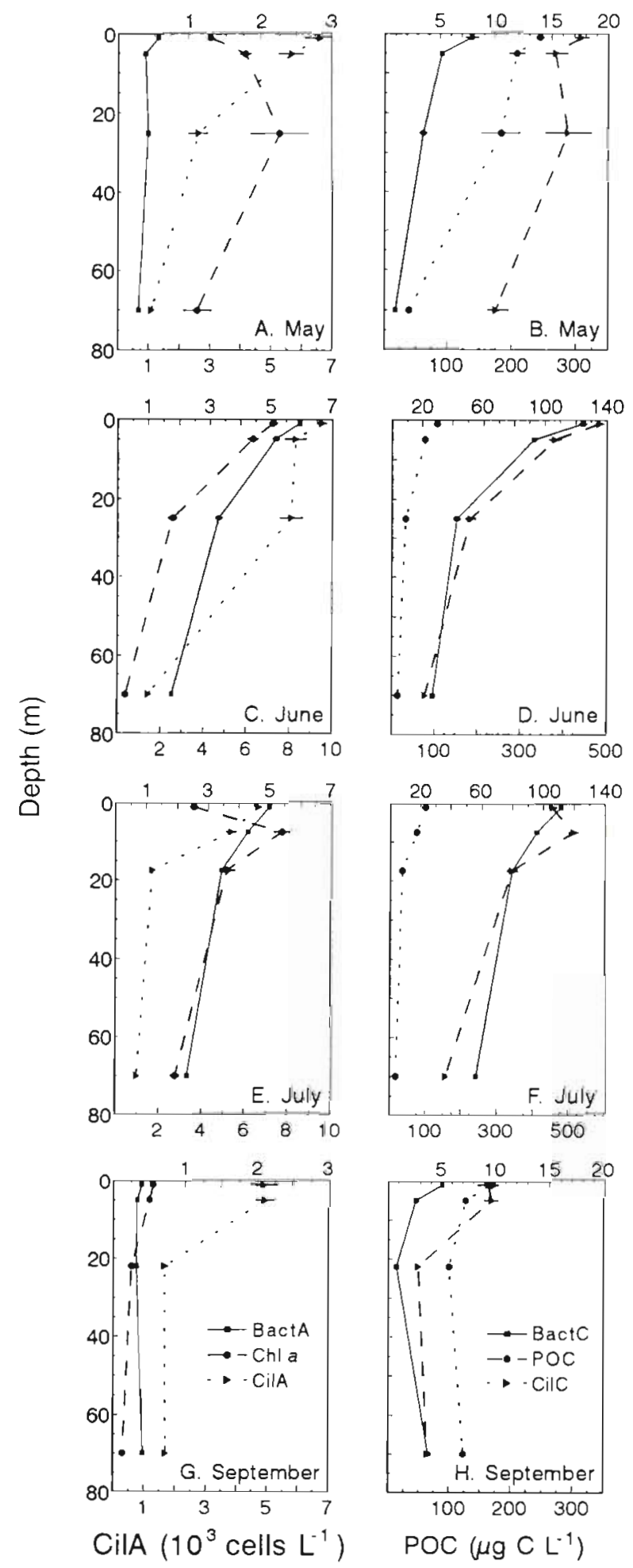

Fig. 4. Vertical profiles of the measured biological variables under study. Data points represent mean \pm 0.1 standard error (SE), i.e. the variability between stations. Acronyms as in Table 3 

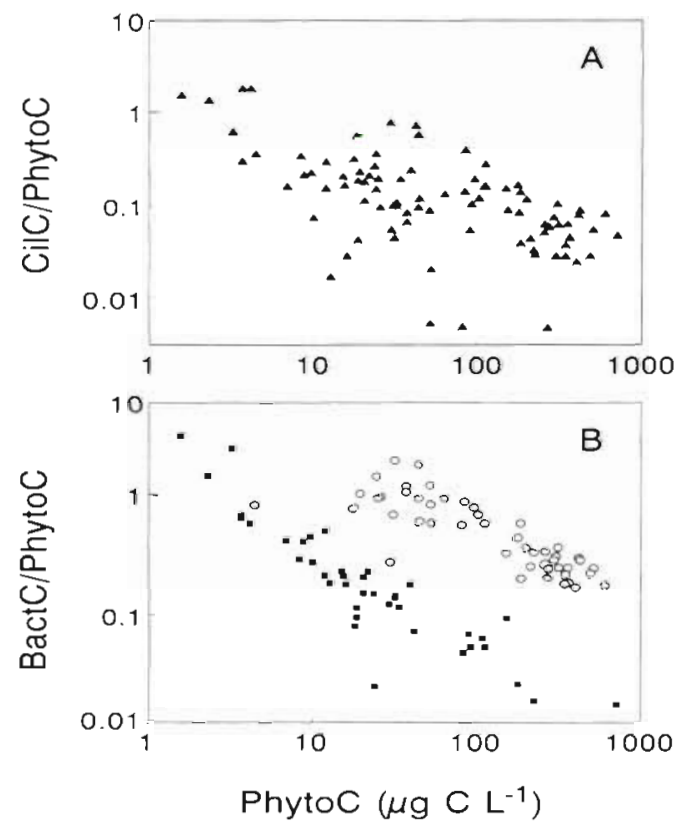

Fig. 5. Relations between (A) PhytoC and CilC:PhytoC (4); and (B) PhytoC and BactC:Phyto $C_{i}$ water samples collected in

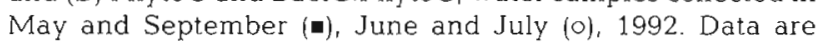
log-transformed. Acronyms as in Table 3

ratios and PhytoC (Fig. 5A), the scattering of log-transformed data for the BactC:PhytoC ratios versus PhytoC plot exhibited 2 different patterns depending on season. At similar PhytoC levels, BactC:PhytoC ratios were higher in June and July than in May and September (Fig. 5B), implying an accumulation of bacterial biomass during the phytoplankton summer growing season.

\section{Relationships with particulate organic carbon}

From May to July, BactC, CilC, and PhytoC were significantly correlated with POC, and accounted for $1-19,3-6$ and $53-86 \%$ of POC, respectively (Table 8 ). However, BactC, CilC and PhytoC together contributed more than $100 \%$ of POC in June. This provides evidence that traditional measurements of particulate matter retained on combusted GF/F filters $(\sim 0.7 \mu \mathrm{m}$ porosity) could underestimate the total amount of planktonic particles. In September, BactC was significantly correlated with POC, while the slopes for the regressions of $\mathrm{CilC}$ and PhytoC versus $\mathrm{POC}$ were not significantly different from zero. This indicates that bacteria represented 3\% of POC in September while ciliate and phytoplankton did not significantly contribute to POC. Overall, BactC, CilC and PhytoC represented 16,4 and $72 \%$ of POC (Table 8 ).
Table 8 . Linear regression statistics between the carbon biomass of bacteria, ciliates and phytoplankton versus POC ( $Y=$ Slope $\times \mathrm{POC}+Y$-int.). Dependent and independent variables

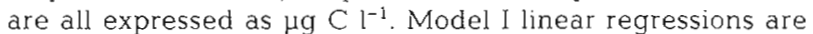
used here because the main purpose is to calculate the carbon contributions of each biological variable to POC, and not to derive functional relationships for which model 11 regressions would be more appropriate. Acronyms as in Table 3. SE: standard error

\begin{tabular}{|lllccc|}
\hline $\begin{array}{l}\text { Sampling } \\
\text { date (n) }\end{array}$ & $\begin{array}{l}\text { Variable } \\
(Y)\end{array}$ & Slope \pm SE & $Y$-int. & $r^{2}$ & $p$ \\
\hline May & BactC & $0.01 \pm 0.003$ & 3.3 & 0.35 & 0.016 \\
$(16)$ & CilC & $0.04 \pm 0.01$ & -0.75 & 0.75 & 0.0001 \\
& PhytoC & $0.77 \pm 0.11$ & -59.83 & 0.77 & 0.0001 \\
& & & & \\
Jun & BactC & $0.19 \pm 0.03$ & 18.93 & 0.67 & 0.0001 \\
$(25)$ & CilC & $0.06 \pm 0.01$ & 0.34 & 0.59 & 0.0001 \\
& PhytoC & $0.86 \pm 0.07$ & -27.29 & 0.86 & 0.001 \\
Jul & BactC & $0.10 \pm 0.02$ & 49.68 & 0.56 & 0.001 \\
$(25)$ & CilC & $0.03 \pm 0.01$ & 1.61 & 0.33 & 0.002 \\
& PhytoC & $0.53 \pm 0.10$ & -18.44 & 0.53 & 0.0001 \\
Sep & BactC & $0.03 \pm 0.01$ & 1.0 & 0.28 & 0.005 \\
$(26)$ & CilC & $0.02 \pm 0.03$ & 3.1 & 0.03 & 0.419 \\
& PhytoC & $0.06 \pm 0.05$ & 8.65 & 0.06 & 0.245 \\
& & & & & \\
Overall & BactC & $0.16 \pm 0.02$ & 3.51 & 0.44 & 0.0001 \\
(92) & CilC & $0.04 \pm 0.004$ & 0.88 & 0.46 & 0.0001 \\
& PhytoC & $0.72 \pm 0.05$ & -49.12 & 0.71 & 0.0001 \\
& & & & & \\
\hline
\end{tabular}

\section{Path analysis}

Path analysis was used to evaluate the importance of direct links between mean water-column temperature and integrated BactC, CilC, and PhytoC (Fig. 6). All significant path coefficients were positive, and showed

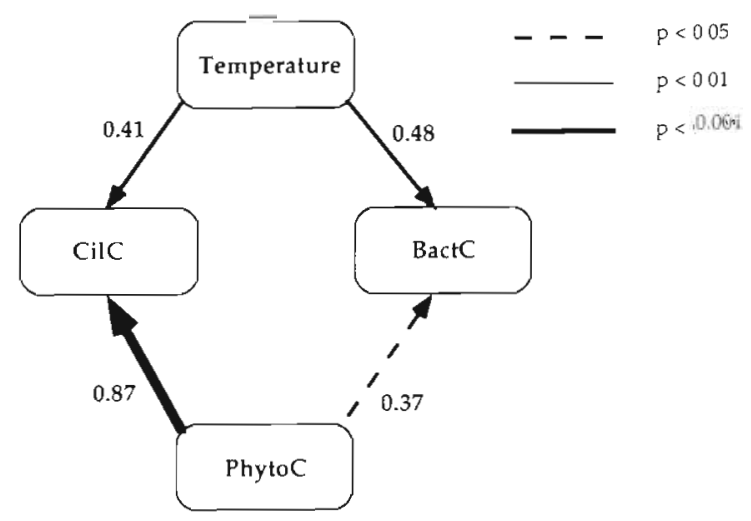

Fig. 6. Schematic representation of the path analysis. Arrows indicate significant path coefficients (shown beside each arrow) between the tested variables (see 'Methods'). Acronyms as in Table 3 
oriented links from temperature to $\mathrm{CilC}$ and $\mathrm{BactC}$, and from PhytoC to $\mathrm{CllC}$ and BactC. The links from temperature to PhytoC and from $\mathrm{CilC}$ to $\mathrm{BactC}$ were not significant, so the path coefficients for these links are not shown here. The highest path coefficient was from PhytoC to CilC $(0.87, \mathrm{p}<0.001)$.

\section{Grazing impact}

Micrograzer assemblages were mostly constituted of ciliated protozoa $\left(10^{3}\right.$ to $10^{4}$ cells $\left.\mathrm{l}^{-1}\right)$ with sizes up to $>15$-fold larger than the size of the dominant diatom prey (see species composition; Fig. 3). Natural samples used for the dilution experiments also contained het-

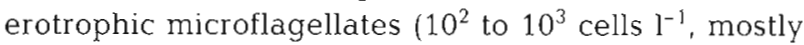
represented by dinoflagellates), and metazoan zooplankton (dominated by calanoid copepods, $\sim 10^{2}$ ind. $\mathrm{I}^{-1}$ ). Direct observations under the microscope revealed some protozoan cells with up to 10 ingested diatom cells within their body. One specimen with at least 8 visible cells of Thalassiosira sp. (the major bloom species in July) within its body is presented in Fig. 3r.

Table 9. Instantaneous coefficients of phytoplankton growth rates $\left(k, \mathrm{~d}^{-1}\right)$ and population mortality $\left(g, \mathrm{~d}^{-1}\right)$ due to microzooplankton grazing in the Lower St. Lawrence Estuary in July 1992. Coefficients of determination $\left(\mathrm{r}^{2}\right)$ for all regression analyses are listed $k$ and $g$ were determined from the dilution technique (Landry \& Hassett 1982, cf. 'Methods'). Per individual clearance rates $\left(C R, \mu l h^{-1}\right)$ were estimated by dividing the estimate of the grazing rates $(g)$ by the density of microzooplankton determined from microscopical counts. $0.01 \leq p \leq$ $0.001 ;$ ns: not significant

\begin{tabular}{|c|c|c|c|c|c|c|}
\hline Stn & $\begin{array}{l}\text { Sampling } \\
\text { depth }(\mathrm{m})^{\alpha}\end{array}$ & $\begin{array}{l}\text { Sample } \\
\text { treatment }\end{array}$ & $k$ & $g$ & $r^{2}$ & $\mathrm{CR}$ \\
\hline \multirow[t]{2}{*}{1} & 12 & Unscreened & 0.10 & 0.05 & $0.99^{\circ}$ & 0.77 \\
\hline & 12 & Prescreened ${ }^{\mathrm{b}}$ & 0.09 & 0.08 & $0.96^{\circ}$ & 1.07 \\
\hline 2 & 10 & Unscreened & 0.04 & 0.01 & $0.38^{\circ}$ & 0.13 \\
\hline 3 & 20 & Unscreened & 0.07 & 0.01 & $0.05^{\mathrm{ns}}$ & 0.17 \\
\hline 4 & 10 & Unscreened & 0.07 & 0.01 & $0.04^{\mathrm{ns}}$ & 0.12 \\
\hline \multirow[t]{2}{*}{5} & 10 & Unscreened & 0.13 & 0.09 & $0.94^{\circ}$ & 2.04 \\
\hline & 10 & Prescreened $^{\mathrm{b}}$ & 0.14 & 0.12 & $0.88^{\circ}$ & 2.72 \\
\hline \multirow[t]{2}{*}{6} & 5 & Unscreened & 0.10 & 0.07 & $0.99^{\circ}$ & 0.29 \\
\hline & 70 & Unscreened & 0.03 & 0.002 & $0.01^{\mathrm{ns}}$ & 0.06 \\
\hline \multicolumn{7}{|c|}{$\begin{array}{l}\text { Seawater dilution experiments were conducted at the } \\
\text { depth of chl a maximum of the survey stations. At } \operatorname{Stn} 6 \text {, } \\
\text { an additional experiment was carried out with bottom } \\
\text { water }(70 \mathrm{~m})\end{array}$} \\
\hline \multicolumn{7}{|c|}{$\begin{array}{l}{ }^{b} \text { Prescreened samples correspond to }<160 \mu \mathrm{m} \text { screened } \\
\text { seawater using Nitex netting }\end{array}$} \\
\hline
\end{tabular}

The results of 9 dilution experiments estimating phytoplankton growth and microzooplankton grazing coefficients are presented in Table 9. As the coefficients measured in unscreened water from the subsurface chl a maximum at Stns $3(20 \mathrm{~m})$ and $4(10 \mathrm{~m})$, and from the deep water at Stn $6(70 \mathrm{~m})$ were not statistically significant $\left(r^{2} \leq 5 \%, p>0.05\right)$, they are excluded from comparisons. In unscreened samples from the subsurface chl a maximum at Stns $1(12 \mathrm{~m}), 2(10 \mathrm{~m}), 5$ $(10 \mathrm{~m})$, and $6(5 \mathrm{~m})$, growth coefficients for phytoplankton ranged from 0.04 to $0.13 \mathrm{~d}^{-1}$ (mean $\pm \mathrm{SD}=0.09 \pm$ $0.04 \mathrm{~d}^{-1}$ ). Microzooplankton grazing coefficients and per grazer clearance rates in these samples averaged $0.05 \pm 0.03 \mathrm{~d}^{-1}$ and $0.81 \pm 0.87 \mu \mathrm{l}$ ind..$^{-1} \mathrm{~h}^{-1}$, respectively. The ratios of grazing rates to phytoplankton growth rates ranged from 0.25 to 0.70 (mean $=0.54 \pm$ 0.21).

Interestingly, in individual prescreened samples $(<160 \mu \mathrm{m})$ from the subsurface chl a maximum at Stns 1 and 5, these ratios increased to 0.89 and 0.86 , respectively, because of microzooplankton grazing level increase in screened samples. Indeed, microzooplankton grazing rates were substantially higher in screened than in unscreened samples (1.6- and 1.3fold for Stns 1 and 5, respectively) while phytoplankton growth coefficients were quite similar for both types of samples. Similarly, specific clearance rates in screened samples at Stns 1 and 5 were both 1.4-fold higher than in unscreened samples (Table 9). The numbers of micrograzers in unscreened and screened samples (data not shown) were quite similar, prior to incubations at both stations (ratio unscreened:prescreened samples $=0.99$ ).

\section{DISCUSSION}

During this study, abundance and biomass of ciliates (CilA, CilC) and bacteria (BactA, BactC) (Table 3) fell within the range of summer values recently published for ciliate $\left(0.4\right.$ to $18 \times 10^{3}$ cells l$^{-1}, 1.3$ to $69.4 \mu \mathrm{g} \mathrm{Cl}^{-1}$; Dolan 1991a, Pilling et al. 1992) and bacterial $\left(10^{8}\right.$ to $10^{9}$ cells ${ }^{-1}, 5$ to $300 \mathrm{ugC} \mathrm{l}^{-1}$; Ducklow \& Carlson 1992 , Simon et al. 1992) concentrations in productive coastal waters. Chl a concentrations in the LSLE (Table 3) are similar to values reported for the southern Kattegat. Denmark ( $\leq 20 \mathrm{\mu g} \mathrm{l}^{-1}$; Kiørboe \& Nielsen 1994), but lower than in the Delaware Estuary (USA) (1.1 to $81.7 \mathrm{~g} \mathrm{l}^{-1}$; Hoch \& Kirchman 1993). Although biological variables peaked in the surface water in June and July (Table 4, Fig. 4) when temperature and stratification index of the water column were at their highest levels (Fig. 2), phytoplankton populations seemed to behave differently from ciliate and bacterial populations, relative to the seasonal evolution of the LSLE. 
Indeed, integrated chl a and the derived phytoplankton carbon biomass (PhytoC; Table 2) were not significantly correlated to the mean water-column temperature, while integrated bacterial and ciliate abundances and biomasses were (Table 5).

Our study confirms previous investigations demonstrating a weak relationship between temperature and phytoplankton dynamics, and the short summer growing season of phytoplankton in the LSLE (Sinclair 1978, Levasseur et al. 1984). Although temperature may set the conditions for optimal metabolic activity of algae in the LSLE, phytoplankton populations mainly respond to these changes in water temperature by a shift or a succession in species composition (Levasseur et al. 1984). The bloom in the LSLE occurs about 2 mo later than in adjacent regions, because of the high freshwater discharge which prevents the spring accumulation of phytoplankton (Malone 1977, Sinclair et al. 1981). In addition, the spring freshwater runoff in the LSLE is also known to decrease eddy exchange between surface and deeper waters (due to strong stratification), a situation which contributes to prevention of the seeding of surface waters with phytoplankton cells (Levasseur et al. 1984, Therriault \& Levasseur 1985). Limiting effects of the freshwater runoff in spring are actually considered as the main factor explaining why the mean annual primary production rate in the LSLE (ca $104 \mathrm{~g} \mathrm{C} \mathrm{m}^{-2} \mathrm{yr}^{-1}$ for the whole LSLE and ca $130 \mathrm{~g} \mathrm{C}$ $\mathrm{m}^{-2} \mathrm{yr}^{-1}$ for the plume region under study) is up to about 5-fold lower than in similar ecosystems (e.g. Therriault et al. 1990, and comparative Table in Therriault \& Levasseur 1985). Ammonium was abundant during our study $(0.01$ to $1.6 \mu \mathrm{M}$, mean $=0.4 \mu \mathrm{M})$, suggesting that the phytoplankton in this study was not nutrient limited. Although the concentration of inorganic nutrients (nitrate and silicate) decreased with phytoplankton production and biomass during the growing season, a 2 yr study in the LSLE has shown that nutrients are generally abundant and non-limiting throughout the year in this milieu (Levasseur et al. 1984).

Although heterotrophic flagellates (primarily dinoflageliates, which can at times be responsible for a substantial part of the herbivory in the plankton or serve as alternate food resources for ciliates; Hansen 1991, Lessard 1991, Verity et al. 1993a, Neuer \& Cowles 1994) were not taken into account during our routine counts, we suggest that herbivory by microzooplankton may represent an important factor for the control of the seasonal abundance of phytoplankton in the LSLE. This may lead to an enhancement of the trophic transfer from the dominant small-sized algae to higher trophic levels, which can help explain the prevalence of large-sized copepods and euphausiids (Runge \& Simard 1990) as well as the high abundance and diver- sity of fish larvae (De Lafontaine 1990) in this environment. The potential role of microzooplankton as trophic links in the LSLE is supported here by several observations from field data (see 1 below), direct observations (see 2), and dilution experiments (see 3 ):

(1) Path analysis used in this study to measure the importance of direct links between mean water-column temperature and integrated BactC, CilC, and PhytoC showed that the highest path coefficient $(0.87$. $\mathrm{p}<0.001$ ) was from PhytoC to CilC, while the path coefficient from CilC to BactC was not significant (Fig. 6). This indicates that the phytoplankton $\rightarrow$ microzooplankton trophic pathway may be prevalent over others (such as bacterivory pathway) in the microbial food chain of the LSLE. However, the absence of a significant path coefficient from CilC to BactC could be an outcome of the paucity of data on heterotrophic flagellate seasonal biomass during this study. For example, ciliates may not directly take up bacteria, but they are hypothesized to rely on bacterivorous flagellates as a food resource (Sherr \& Sherr 1984).

Ducklow \& Carlson (1992) suggested that a bacterial-phytoplankton linear relationship that exhibits a positive slope of $<1$ is indicative of grazing limitation of bacterial populations. This was not the case in this study, where the functional slope (model II) of the regression line for PhytoC versus BactC was about 1. In contrast, the functional slope of the regression line for PhytoC versus CilC was less than 1 (Table 7), suggesting (by analogy) that the top-down pressure (i.e. predation) on ciliates was higher than on bacteria. These comparisons imply that the energy transfer from grazing on herbivorous micrograzers probably prevailed over that from bacterivory in the LSLE.

BactC: PhytoC and CilC:PhytoC ratios increased with decreasing PhytoC in the LSLE (Fig. 5), which is a general feature in ecosystems covering oligotrophic and eutrophic situations such as Lake Constance (Geller et al. 1991) or in different ecosystems of varying trophic state (e.g. Simon et al. 1992). The above patterns generally emphasize different aspects of the structure of pelagic food webs, e.g. the increasing dominance of microorganisms and the microbial loop with increasing oligotrophy. However, at similar PhytoC levels, the loglog relationship between BactC:PhytoC ratios and Phyto $C$ in the LSLE exhibited higher ratios in June and July than in May and September (Fig. 5B). This implies an accumulation of bacterial biomass during the phytoplankton summer growing season in the LSLE, probably because of the low level of bacterial loss processes such as bacterivory, as indicated by the slope of the relationship PhytoC versus BactC (see the above paragraph).

This was further supported by the substantial mean contributions of BactC to PhytoC (35\%) and POC $(17 \%)$, although bacterial growth rates and bacterivory 
were not measured during this study. In contrast, CilC averaged 22, 8 and $4 \%$ of BactC, PhytoC and POC, respectively. These relative contributions seem low, compared to other aquatic systems, probably because of the above-mentioned higher predation pressure on ciliates. During large-size diatom (Melosira italica subsp. subarctica) or cyanobacterium (Oscillatoria rubescens) blooms in nutrient-rich lakes, we recently reported higher mean contributions of ciliates to bacterial $(>50 \%)$ and phytoplankton carbon biomass $(>10 \%)$, and lower mean contribution of bacteria $(<25 \%)$ to phytoplankton carbon biomass (Amblard et al. 1993, 1994). Comparison of CilC and BactC contributions to POC is much more difficult, because we found traditional measurements of POC retained on combusted GF/F filters ( $0.7 \mu \mathrm{m}$ porosity) to underestimate the $\mathrm{C}$ composition of planktonic particles. These measurements usually miss half or more of the bacteria (Fuhrman et al. 1989) (many of which were $<0.5 \mu \mathrm{m}$ diameter in our samples), and probably many of the fragile ciliated protozoa, which usually explode in the open air or on contact with rough filters such as GF/F filters (Sime-Ngando et al. 1990). This may explain why BactC, CilC and PhytoC together represented $>100 \%$ of POC in June (Table 8 ).

The above comparisons of (1) the importance of CilC and BactC in relation to other components of the LSLE trophic structure and (2) the slopes of the regression lines Phyto $C$ versus $B a c t C$ and PhytoC versus CilC also suggest that, as PhytoC increases, an increasing proportion of the derived substrate moves into the BactC relative to that into the $\mathrm{CilC}$. However, ciliates seem able to respond more rapidly to phytoplankton variations than bacteria, as shown from 2 lines of evidence. Firstly, the linear Pearson correlation coefficient and the path coefficient between PhytoC and CilC were substantially higher than those between PhytoC and BactC (Table 5, Fig. 6). Secondly, the above-mentioned patterns of decreasing PhytoC with increasing CilC: PhytoC and BactC:PhytoC ratios (Fig. 5) exhibited a PhytoC level corresponding to the maximum CilC: PhytoC ratio which was about 2 -fold higher than that corresponding to the maximum BactC:PhytoC ratio. This indicates that at high phytoplankton standing stock, the LSLE may potentially support more ciliate biomass available for predation than bacterial biomass subject to accumulation.

(2) During this study, ciliated protozoan populations were dominated by individuals with sizes of up to 15fold larger than that of the blooming diatoms (Fig. 3), which is close to the predator-to-prey average size ratio of 8:1 for pelagic ciliates (Hansen et al. 1994) and of about 14:1 for planktonic ecosystems in general (Sheldon et al. 1977). Microscopical direct observations further revealed phagotrophic protozoa with up to 10 ingested bloom-forming diatom cells in their body (Fig. 3r). Such direct observations strongly support our main hypothesis that large microzooplankton are actively preying on small blooming diatoms such as Chaetoceros spp. and Skeletonema sp. in June or Skeletonema sp. and Thalassiosira sp. in July, and that this may be one of the key mechanisms by which protozoan zooplankton affect phytoplankton growth, and subsequently mediate energy transfer from the microbial food web to the higher trophic levels in the LSLE.

(3) Finally, seawater dilution experiments conducted in July 1992 at the level of the chl a maximum indicate that microzooplankton may have an important grazing impact on phytoplankton production in the LSLE, and may constitute a target food source for metazoan zooplankton. However, our estimates of microzooplankton grazing impact on phytoplankton are probably biased because (1) all potential consumers of chl a containing organisms (such as some $<20 \mu \mathrm{m}$ flagellates; cf. Sherr et al. 1991) were not taken into account; and (2) predation among members of the microzooplankton during incubation of plankton samples can be substantial (Verity et al. 1993b).

At Stns 1, 2,5, and 6, where significant coefficients were recorded (Table 9), microzooplankton herbivory rate coefficients (range 0.01 to $0.09 \mathrm{~d}^{-1}$ ) and the estimates of clearance rate per grazer $\left(0.13\right.$ to $2.04 \mu \mathrm{l}$ ind. ${ }^{-1}$ $\mathrm{h}^{-1}$ ) for unscreened samples were in general comparable to those reported from similar ecosystems. In coastal areas, the most frequent microzooplankton grazing rates estimated from the dilution technique ranged from 0.06 to $0.4 \mathrm{~d}^{-1}$ (Landry \& Hassett 1982, Burkill et al. 1987, Gifford 1988, Dolan 1991b, Neuer \& Cowles 1994). Landry \& Hassett (1982) reported microzooplankton specific clearance rates of 0.1 to $1.6 \mu l \mathrm{~h}^{-1}$ for coastal microzooplankton unscreened samples. However, specific clearance rates as high as $85 \mu \mathrm{h} \mathrm{h}^{-1}$ have been reported for coastal tintinnids (Heinbokel 1978, Capriulo \& Carpenter 1980). Our specific clearance rates also fell within the range of values (0.004 to $8.3 \mu$ ind $^{-1} \mathrm{~h}^{-1}$ ) reported for coastal water heterotrophic protists feeding on fluorescently labeled algae (Sherr et al. 1991). At the subsurface depth of chl a maximum, our phytoplankton growth rates (max. of $0.13 \mathrm{~d}^{-1}$; Table 9) in unscreened samples were about 1 order of magnitude lower than the predicted maximum of $0.98 \mathrm{~d}^{-1}$ for $8^{\circ} \mathrm{C}$ (close to our in situ temperature of between 4 and $7^{\circ} \mathrm{C}$ ) and continuous light (Eppley 1972). Neuer \& Cowles (1994) recently reported higher phytoplankton growth rates $\left(0.67\right.$ to $\left.1.58 \mathrm{~d}^{-1}\right)$ from dilution experiments in the Oregon (USA) coastal upwelling system, where phagotrophic protists (including ciliates, thecate and gymnodinoid dinoflagellates, and non-pigmented nanoflagellates) exhibited high herbivory rates (up to $0.6 \mathrm{~d}^{-1}$ ) during the late stages of the 
phytoplankton bloom. The above comparisons suggest that much of the subsurface chlorophyll during our study was probably not photosynthetically active due to limitation by irradiance. This was particularly apparent at Stns 3 and 4 (close to the freshwater plume of the major rivers on the north shore of the LSLE; Fig. 1, see also 'Methods') where the coefficients of the dilution experiments were not significantly different from zero (Table 9), hence the exclusion of these stations from comparisons. Assuming steady state and that the phytoplankton growth rates were similar to those at ambient nutrient levels, microzooplankton grazing activity represented up to $70 \%$ (mean $\pm \mathrm{SD}=54 \pm$ $21 \%)$ of the phytoplankton growth rates in the LSLE (Table 9).

Dilution experiments were also conducted with separated unscreened and prescreened samples $(<160 \mu \mathrm{m})$ from Stns 1 and 5. Microzooplankton grazing rates, the per cell clearance rates, and the ratios of grazing to algal growth rates in prescreened samples were up to 1.6-fold higher than in unscreened samples (Table 9). Microzooplankton numbers in both types of samples were quite similar prior to incubations, implying no cell losses when prescreening raw samples. These results imply that metazoan zooplankton in unscreened samples (represented mainly by calanoid copepods, $\sim 10^{2}$ ind. $\mathrm{l}^{-1}$ ) were able to substantially reduce (probably by their grazing activity) the grazing effort of herbivorous microzooplankton. The in situ metazoan predation on microzooplankton is probably more important than indicated here because the bottle sampling technique used in this study certainly does not quantitatively capture metazooplankton such as the dominant large-sized copepods. The above observation is consistent with the recent study by Ohman \& Runge (1994) suggesting that heterotrophic microplankton may be the main prey resource for net lipid synthesis and egg production for the dominant copepod (i.e. Calanus finmarchicus) in the low-chlorophyll waters of the Gulf of St. Lawrence, in late June and early July.

In conclusion, this study provides evidence for the potential of microzooplankton assemblages as a trophic link between phytoplankton and metazoan zooplankton in the LSLE, complementing other reports on the role of herbivorous protozoa as key intermediates in the functioning of pelagic ecosystems. The data presented here may help explain the apparent paradox of low annual algal production and large standing stock of metazoan zooplankton in the LSLE. Further analysis of the seasonal patterns of phagotrophic flagellate biomass, bacterivory, microzooplankton growth rates, influence on nutrient regeneration rates, competition with metazoan herbivores, and the importance of predation, along with variations in physical environment, will provide a more complete understanding of the role of the microzooplankton compartment in the St. Lawrence Estuary.

Acknowledgements. This research was supported by grants from the FODAR (Fonds pour le Développement et l'Avancement de la Recherche, Université du Québec), the FIR-UQAR (Fonds Institutionnel de Recherche, Université du Québec à Rimouski), the Fonds FCAR of Quebec, the Natural Sciences and Engineering Research Council of Canada and the 'Programme d'actions structurantes du Ministère de l'enseignement supérieur et de la science' of Quebec. We thank the crew of the MV 'Alcide C. Horth'; A. Bélanger, L. Cormier, H. Lambert and L. Lorrain for assistance in the field and in the laboratory; M. Bourgeois, M.-C. Croteau, B. Ramirez, and P. Rivard for the enumeration of bacteria and phytoplankton; C. Belzile for help with data analyses; and anonymous reviewers for comments. This is a contribution to the research programmes of G.R.E.C. (Groupe de recherche en environnement côtier) and CNRS-URA 1944 (Biologie Comparée des Protistes).

\section{LITERATURE CITED}

Allali K, Dolan J, Rassoulzadegan F (1994) Culture characteristics and orthophosphate excretion of a marine oligotrich ciliate, Strombidium sulcatum, fed heat-killed bacteria. Mar Ecol Prog Ser 105:159-165

Amblard C, Bourdier G, Sime-Ngando T, Rachiq S, Carrias JF (1994) Diel and vertical variations of the microbial stocks (bacteria, heterotrophic flagellates, ciliates, phytoplankton) and their relative activities. In: Feuillade J (ed) Studies on Lake Nantua (France). A eutrophic lake on the way of rehabilitation. Arch Hydrobiol Beih Ergebn Limnol 41: $125-144$

Amblard C, Sime-Ngando T, Rachiq S, Bourdier G (1993) Importance of ciliated protozoa in relation to the bacterial and phytoplanktonic biomass in an oligo-mesotrophic lake, during the spring diatom bloom. Aquat Sci 55:1-9

Bernard C, Rassoulzadegan F (1993) The role of picoplankton (cyanobacteria and plastidic picoflagellates) in the diet of tintinnids. J Plankton Res 15:361-373

Burkill PH, Mantoura RFC, Llewellyn CA, Owens NJP (1987) Microzooplankton grazing and selectivity of phytoplankton in coastal waters. Mar Biol 93:581-590

Capriulo GM. Carpenter EJ (1980) Grazing by 35 to $202 \mu \mathrm{m}$ microzooplankton in Long Island Sound. Mar Biol 56: $319-326$

Corliss JO (1979) The culiate protozoa: characterisation, classification and guide to the literature, 2nd edn. Pergamon Press, New York

Cushing DH (1971) Upwelling and fish production. Adv mar Biol 9:255-334

De Lafontaine Y (1990) Ichthyoplankton communities in the St. Lawrence Estuary: composition and dynamics. In: ElSabh MI, Silverberg $N$ (eds) Oceanography of a large scale estuarine system. The St. Lawrence. Sprnger-Verlag, New York, p 321-343

De Mendiola BR (1974) Food of the larval Anchoveta Engraulis ringiens. In: Blaxter JHS (ed) The early life history of fish. Springer-Verlag, New York, p 277-285

Dolan JR (1991a) Microphagous ciliates in mesohaline Chesapeake Bay waters: estimates of growth rates and consumption by copepods. Mar Biol 111:303-309 
Dolan JR (1991b) Guilds of ciliate microzooplankton in the Chesapeake Bay. Estuar coast Shelf Sci 33:137-152

Dolan JR (1992) Mixotrophy in ciliates: a review of chlorella symbiosis and chloroplast retention. Mar microb Food Webs 6:115-132

Dolan JR, Coats DW (1990) Seasonal abundance of planktonic ciliates and microflagellates in mesohaline Chesapeake Bay waters. Estuar coast Shelf Sci 31:157-175

Ducklow HW, Carlson CA (1992) Oceanic bacterial production. In: Marshall KC (ed) Advances in microbial ecology. Plenum Press, New York, p 113-181

El-Sabh MI (1988) Physical oceanography of the St. Lawrence Estuary. In: Kjerfve B (ed) Hydrodynamics of estuaries, Vol II. CRC Press, Boca Raton, p 61-78

El-Sabh MI, Silverberg N (1990) Oceanography of a large scale estuarine system: the St. Lawrence. Springer-Verlag. New York

Eppley RW (1972) Temperature and phytoplankton growth in the sea. Fish Bull US 70:1063-1085

Ferrier-Pagès C, Rassoulzadegan F (1994) N remineralization in planktonic protozoa. Limnol Oceanogr 39:411-419

Fuhrman JA, Sleeter TD, Carlson CA, Proctor LM (1989) Dominance of bacterial biomass in the Sargasso Sea and its ecological implications. Mar Ecol Prog Ser 57:207-217

Geller W, Berberovic R, Gaedke U, Müller H, Pauli HR, Tilzer MM, Weisse T (1991) Relations among the components of autotrophic and heterotrophic plankton during the seasonal cycle 1987 in Lake Constance. Verh int Ver Limnol $24: 831-836$

Gifford DJ (1988) Impact of grazing by microzooplankton in the northeast arm of Halifax Harbor, Nova Scotia. Mar Ecol Prog Ser 47:249-258

Gifford DJ, Dagg MJ (1988) Feeding of the estuarine copepod Acartia tonsa Dana: carnivory vs herbivory in natural microplankton assemblages. Bull mar Sci 43:458-468

Hansen B, Bjornsen PK, Hansen PJ (1994) The size ratio between planktonic predators and their prey. Limnol Oceanogr 39:395-403

Hansen PJ (1991) Quantitative importance and trophic role of heterotrophic dinoflagellates in a coastal pelagial food web. Mar Ecol Prog Ser 73:253-261

Hartmann HJ, Hassan T, Aleya L, Lair N (1993) Predation on ciliates by suspension-feeding calanoid copepod Acanthodiaptomus denticornis. Can J Fish Aquat Sci 50:1382-1393

Heinbokel JF (1978) Studies on the functional role of tintinnids in the Southern California Bight. II. Grazing rates of field populations. Mar Biol 47:191-197

Hoch MP, Kirchman DL (1993) Seasonal and inter-annual variability in bacterial production and biomass in a temperate estuary. Mar Ecol Prog Ser 98:283-295

Holm-Hansen O, Lorenzen CJ, Holmes RW, Strickland JDH (1965) Fluorometric determination of chlorophyll. J Cons int Explor Mer 30:3-15

Jonsson PR, Tiselius P (1990) Feeding behaviour, prey detection, and capture efficiency of the copepod Acartia tonsa feeding on planktonic ciliates. Mar Ecol Prog Ser 60:35-44

Kiorboe T, Nielsen TG (1994) Regulation of zooplankton biomass and production in a temperate, coastal ecosystem. 1. Copepods. Limnol Oceanogr 39:493-507

Landry MR, Hassett RP (1982) Estimating the grazing impact of marine microzooplankton. Mar Biol 67:283-288

Legendre L, Legendre P (1984) Écologie numérique, Tome 2, La structure des données écologiques, 2e éd. Collect Écol 13, Masson, Paris

Legendre P, Vaudor A. (1991) The R package for multivariate data analysis. Département des Sciences Biologiques, Université de Montréal
Lessard E (1991) The trophic role of heterotrophic dinoflagellates in diverse marine environments. Mar microb Food Webs 5:49-58

Levasseur M, Therriault JC, Legendre L (1984) Hierarchical control of phytoplankton succession by physical factor. Mar Ecol Prog Ser 19:211-222

Lund JWG, Kupling C, Le Cren ED (1958) The inverted microscope method of estimating algal numbers and the statistical basis of estimations by counting. Hydrobiologia 11: $143-170$

Malone TC (1977) Light-saturated photosynthesis by phytoplankton size fractions in the New York Bight, U.S. Mar Biol 42:281-292

Marshall SM (1969) Protozoa. Order: Tintinnida. In: Fraser $\mathrm{JH}$, Hansen VK (eds) Fiches d'identification du zooplancton. Cons perm int explor Mer, Charlottenlund, p 117-127

Morel A, Ahn YH (1991) Optics of heterotrophic nanoflagellates and ciliates: a tentative assessment of their scattering role in oceanic waters compared to those of bacterial and algal cells. J mar Res 49:1-26

Neuer S, Cowles TJ (1994) Protist herbivory in the Oregon upwelling system. Mar Ecol Prog Ser 113:147-162

Neyman J, Scott EL (1960) Correction for bias introduced by a transformation of variables. Ann math Statist 31:643-661

Nielsen TG, Kiørboe T (1994) Regulation of zooplankton biomass and production in a temperate, coastal ecosystem. 2. Ciliates. Limnol Oceanogr 39:508-519

Ohman MD, Runge JA (1994) Sustained fecundity when phytoplankton resources are in short supply: omnivory by Calanus finmarchicus in the Gulf of St. Lawrence. Limnol Oceanogr 39:21-36

Paasche E, Kristiansen S (1982) Ammonium regeneration by microzooplankton in the Oslofjord. Mar Biol 69:55-63

Painchaud J, Therriault JC (1989) Relationships between bacteria, phytoplankton and particulate organic carbon in the Upper St. Lawrence Estuary. Mar Ecol Prog Ser 56: 301-311

Parsons TR, Maita Y, Lalli CM (1984) A manual of chemical and biological methods for seawater analysis. Pergamon Press, Toronto

Pilling ED, Leakey RJG, Burkill PH (1992) Marine pelagic ciliates and their productivity during summer in Plymouth coastal waters. J mar biol Ass UK 72:265-268

Porter KG, Feig YS (1980) The use of DAPI for identifying and counting aquatic microflora. Limnol Oceanogr 25:943-948

Porter KG, Pace ML, Battey JF (1979) Ciliated protozoa as links in freshwater planktonic food chains. Nature 277: 563-565

Putt M, Stoecker DK (1989) An experimentally determined carbon: volume ratio for marine 'oligotrichous' ciliates from estuarine and coastal water. Limnol Oceanogr 34 $1097-1103$

Rassoulzadegan F, Laval-Peuto M, Sheldon RW (1988) Partitioning of the food ration of marine ciliates between picoand nanoplankton. Hydrobiologia 159:75-88

Ricker WE (1973) Linear regression in fishery research. J Fish Res Bd Can 30:409-434

Rivier A, Brownlee DC, Sheldon RW, Rassoulzadegan F (1985) Growth of microzooplankton: a comparative study of bactivorous zooflagellates and ciliates. Mar microb Food Webs 1:51-60

Robertson JR (1983) Predation by estuarine zooplankton on tintinnid ciliates. Estuar coast Shelf Sci 16:27-36

Runge JA, Simard Y (1990) Zooplankton of the St. Lawrence Estuary: the imprint of physical processes on its composition and distribution. In: El-Sabh MI, Silverberg N (eds) Oceanography of a large scale estuarine system. The St. 
Lawrence. Springer-Verlag, New York, p 296-320

Ryder RA (1881) The protozoa and protophytes considered as the primary or indirect source of the food of fishes. Bull US Fish Comm 1:236-251

Ryther JH (1969) Photosynthesis and fish production in the sea. The production of organic matter and its coversion to higher forms of life vary throughout the world ocean. Science 166:72-76

Sakshaug E, Andreses K, Myklestad S, Olsen Y (1983) Nutrient status of phytoplankton communities in Norwegian waters (marine, brackish and fresh) as revealed by their chemical composition. J Plankton Res 5:175-196

Sharp JH (1974) Improved analysis for 'particulate' organic carbon and nitrogen from seawater. Limnol Oceanogr 19: $984-988$

Sheldon RW, Sutcliffe WH Jr, Paranjape MA (1977) Structure of pelagic food chain and relationship between plankton and fish production. J Fish Res Bd Can 34:2344-2353

Sherr BF, Sherr EB (1984) Role of heterotrophic protozoa in carbon and energy flow in aquatic ecosystems. In: KIug MJ, Reddy CA (eds) Current perspectives in microbial ecology. American Society for Microbiology, Washington, DC, p 412-423

Sherr EB, Sherr BF (1987) High rates of consumption of bacteria by pelagic ciliates. Nature 325:710-711

Sherr EB, Sherr BF, McDaniel J (1991) Clearance rates of $<6 \mu \mathrm{m}$ fluorescently labeled algae (FLA) by estuarine protozoa: potential grazing impact of flagellates and ciliates. Mar Ecol Prog Ser 69:81-92

Sieracki ME, Verity PG, Stoecker DK (1993) Plankton community response to sequential silicate and nitrate depletion during the 1989 North Atlantic spring bloom. Deep Sea Res ll 40:213--225

Silver MW, Gowing MM, Brownlee DC, Corliss JO (1984) Ciliated protozoa associated with oceanic sinking detritus. Nature 309:246-248

Sime-Ngando T, Bourdier G, Amblard C, Pinel-Alloul B (1991) Short-term variations in specific biovolumes of different bacterial forms in aquatic systems. Microb Ecol 21. $211-226$

Sime-Ngando T, Grolière CA (1991) Quantitative effects of flxatives on the storage of freshwater planktonic ciliates. Arch Protistenkd 140:109-120

Sime-Ngando T, Hartmann HJ, Grolière CA (1990) Rapid quantification of planktonic ciliates: comparison of improved live counting with other methods. Appl environ Microbiol 56:2234-2242

Sime-Ngando T, Juniper K, Vézina A (1992) Ciliated protozoan communities over Cobb seamount: increase in biomass and spatial patchiness. Mar Ecol Prog Ser 89:37-51

Simon M, Azam F (1989) Protein content and protein synthesis rates of planktonic marine bacteria. Mar Ecol Prog Ser $51: 201-213$

Simon M, Cho BC, Azam F (1992) Significance of bacterial biomass in lakes and the ocean: comparison to phytoplankton biomass and biogeochemical implications. Mar Ecol Prog Ser 86:103-110

Sinclair M (1978) Summer phytoplankton varability in the lower St. Lawrence estuary. J Fish Res Bd Can 35: $1171-1185$

Responsible Subject Editor: F. Rassoulzadegan, Villetranchesur-Mer. France
Sinclair M, Subba Rao PV, Couture R (1981) Phytoplankton temporal distribution in estuaries. Oceanol Acta 4: $239-246$

Small EB, Lynn DH (1985) Phylum Ciliophora Doflein, 1901 In: Lee JJ, Hufner SH, Bovee EC (eds) Illustrated guide to the Protozoa. Society of Protozoologists, Lawrence, KS, p $393-575$

Smetacek V (1981) The annual cycle of protozooplankton in the Kiel Bight. Mar Biol 63:1-11

Sokal RR, Rohlf FJ (1981) Biometry: the principles and practice of statistics in biological research, 2 nd edn. WH Freeman and Co, San Francisco

Stoecker DK, Capuzzo JM (1990) Predation on protozoa: its importance to zooplankton. J Plankton Res 12:891-908

Stoecker DK, Egloff DA (1987) Predation by Acartia tonsa Dana on planktonic ciliates and rotifers. J exp mar Biol Ecol 110:53-68

Stoecker DK, Sieracki ME, Verity PG, Michaels AE, Haugen E, Burkill PH, Edwards ES (1994) Nanoplankton and protozoan microzooplankton during the JGOFS North Atlantic bloom experiment: 1989 and 1990. J mar biol Ass UK 74:427-443

Suzuki MT, Sherr EB, Sherr BF (1993) DAPI direct counting underestimates bacterial abundances and average cell size compared to $\mathrm{AO}$ direct counting. Limnol Oceanogr $38: 1566-1570$

Therriault JC, Legendre L, Demers S (1990) Oceanography and ecology of phytoplankton in the St. Lawrence estuary. In: El-Sabh MI, Silverberg $N$ (eds) Oceanography of a large scale estuarine system. The St. Lawrence. SpringerVerlag, New York, p 269-295

Therriault JC, Levasseur M (1985) Control of phytoplankton production in the Lower St. Lawrence Estuary: light and freshwater runoff. Nat can 112:77-96

Throndsen J (1978) Preservation and storage. In: Sournia A (ed) Phytoplankton manual. UNESCO, Paris, p 69-74

Verity PG (1991) Measurement and simulation of prey uptake by marine planktonic ciliates fed plastidic and aplastidic nanoplankton. Limnol Oceanogr 36:729-750

Verity PG, Stoecker DK, Sieracki ME, Burkill PH, Edwards ES, Tronzo CR (1993a) Abundance, biomass and distribution of heterotrophic dinoflagellates during the North Atlantic spring bloom. Deep Sea Res II 40:227-244

Verity PG, Stoecker DK, Sieracki ME, Nelson JR (1993b) Grazing, growth and mortality of microzooplankton during the 1989 North Atlantic spring bloom at $47^{\circ} \mathrm{N}, 18^{\circ} \mathrm{W}$. Deep Sea Res I 40:1793-1814

Verity PG, Yoder JA, Bishop SS, Nelson JR, Craven DB, Blanton JO, Robertson CY, Tronzo CR (1993c) Composition, productivity and nutrient chemistry of a coastal ocean planktonic food web. Cont Shelf Res 13:741-776

Wiadnyana NN, Rassoulzadegan F (1989) Selective feeding of Acartia clausi and Centropages typicus on microzooplankton. Mar Ecol Prog Ser 53:37-45

Yentsch CS, Menzel DW (1963) A method for the determination of phytoplankton chlorophyll and phaeophytin by fluorescence. Deep Sea Res 10:221-231

Zweifel UL, Hagstrom A (1995) Total counts of marine bacteria include a large fraction of non-nucleoid-containing bacteria (ghosts). Appl environ Microbiol 61:2180-2185

Manuscript first received: April 19, 1995

Revised version accepted: October 4,1995 